\title{
PLANTS
}

\section{NOTES ON BIOLOGY AND ECOLOGY OF THE PRAIRIE CROCUS (ANEMONE PATENS L.) AND ITS CURRENT STATUS IN SASKATCHEWAN}

\section{VLADIMIR V. KRICSFALUSY ${ }^{1}$, YAKIV P. PONOMARENKO²}

${ }^{1}$ School of Environment and Sustainability, University of Saskatchewan, 117 Science Place, Saskatoon SK S7N 5C8, Canada email: vladimir.k@usask.ca

${ }^{2}$ Department of Biology, University of Saskatchewan, 112 Science Place, Saskatoon SK S7N 5E2, Canada email: yap803@mail.usask.ca

\section{INTRODUCTION}

The prairie crocus (Anemone patens $\mathrm{L}$. sensu lato) is a perennial herb widespread through the temperate regions of the Northern Hemisphere, comprising a few different subspecies. ${ }^{1}$ It ranges from Europe to North America, passing through Central, North and Eastern Europe as well as Central and North Asia, and reaching the central part of North America covering a wide range of climatic and habitat conditions. It should be noted that $A$. patens var. multifida Pritz. is confined to the eastern section of the species' distribution range (AsiaNorth America), while the western section (Europe) is dominated by $A$. patens var. patens. Overlapping of these taxa occurs in Central Asia.

A. patens is considered to be resistant to disturbances and can tolerate human influence to some extent. However, its conservation is of growing concern in some parts of the world, especially in Europe where the general population is dramatically declining and hence this species is included in the European Red List of vascular plants, ${ }^{2}$ as well as in national Red Data Books of most European countries where this plant is present. In North America, $A$. patens is relatively well represented in the United States and Canada and has limited legal protection in some of the states and provinces of these countries. This plant is strongly associated with native prairies, ${ }^{3}$ which are some of the most endangered ecosystems of North America. For the whole continent, native mixed and short-grass prairies have declined to less than $20 \%$ of their original extent. ${ }^{4}$ In the prairie provinces of Canada, although it 
is a widespread and familiar plant, much is still unknown about the species' biology and ecology as well as the processes that may threaten its local survival, for example in Saskatchewan, where the range of $A$. patens has been contracting over the past few decades, particularly in the vicinity of major urban centres like Regina and Saskatoon. .,6,7 $^{2}$

A. patens is an important species not only from a biological and ecological perspective but also from a cultural point of view, being present in horticulture, traditional medicine, folklore and symbols. As a widespread plant across North America, $A$. patens has been used by many native tribes as a treatment for several illnesses. For example, in Saskatchewan the Blackfoot applied a poultice of crushed leaves topically as a counterirritant. They also used this plant to speed birth delivery by taking a decoction of the plant. ${ }^{8,9} A$. patens has an important symbolic value among North American native peoples, as well as some Scandinavian and Slavic nations in Europe. As in ancient Greece, this plant is a herald of the arriving spring. ${ }^{10,11}$ A. patens is also present in more "formal" symbolism. In Europe this species is adopted as the official floral emblem of two provinces Häme and South Karelia, Finland.
In North America A. patens is considered to be the provincial flower of Manitoba and the state flower of South Dakota. It also appears on the Coat of Arms of Manitoba and of the City of Winnipeg. Recently, a special monument was erected in Arden, Manitoba to celebrate $A$. patens as a heritage plant. ${ }^{12}$ The image of A. patens has also been profusely used in collectable items, including postage stamps in many countries and the world's purest gold coin in Canada. ${ }^{13}$

The goals of this study of A. patens are to (i) clarify its taxonomic status, (ii) expand the current knowledge of biology and ecology of the species, and (iii) contribute to biodiversity conservation in Saskatchewan.

\section{METHODS \\ Study Site}

During May-July of 2011 and 2012 , we conducted studies of the biology and ecology of $A$. patens and surveyed its distribution in Saskatchewan, placing a particular emphasis on provincially protected areas. Surveyed sites included Prince Albert National Park, The Battlefords Provincial Park, Cypress Hills Interprovincial Park, Redberry Lake Biosphere Reserve, and several conservation areas in the city of Saskatoon and its vicinity: Beaver Creek, 
Cranberry Flats, Crocus Prairie, Kernen Prairie, McKercher, Northeast Swale, Peturrson's Ravine, Saskatoon Natural Grassland, and Wanuskewin Heritage Park. For more details on the distribution of $A$. patens in Saskatchewan refer to the study by Kricsfalusy et al. ${ }^{7}$

On 19 July 2011, we sampled a patch of fescue prairie on private land about $25 \mathrm{~km}$ northwest of Hafford which is located within the Redberry Lake Biosphere Reserve area (Figure 1). In the process, we found a flowering population of $A$. patens growing on a heavily grazed pasture that was separated from the fescue prairie by a fence. Some of the plants were evidently flowering repeatedly, because they bore well-formed seed heads from spring flowering as well as newly opened flowers. The new flowers were smaller and paler in colour than those we had observed in other populations during the regular April-May flowering season. Because of this unusual mid-summer flowering event, we re-visited this site next year, on 7 July 2012 . This time there was no observed mid-summer flowering, and only a few plants had flowered and fruited earlier in the spring.

\section{Sampling Approach}

We performed a detailed survey of $A$. patens in the study site within a $10 \mathrm{~m} \times 10 \mathrm{~m}$ plot that was staked out over a representative part of the population. The site location and the following conditions of the population were recorded: elevation (obtained using a Garmin eTrex handheld GPS unit), aspect, slope position, percent vegetation cover, litter, bare soil, and type and degree of disturbance (grazing, trampling, burning, burrowing, and invasive species). All higher vascular plant species within the plot were recorded, along with their percent cover.

Soil samples were taken so that they contained a mix of the upper $30 \mathrm{~cm}$ horizon where the roots of A. patens are mainly distributed. Rangeland type was estimated based on land surface and soil profile examination according to Thorpe. ${ }^{14}$

\section{RESULTS \& DISCUSSION}

\section{Taxonomic Considerations}

A. patens is commonly known under several names in different parts of the world, such as prairie crocus, prairie smoke, prairie pasqueflower, eastern pasqueflower, American pasqueflower, European pasqueflower, sticky pasqueflower, pulsatille, pulsatille multifide, crocus anemone, cutleaf anemone, gosling plant, lionsbeard, wild crocus, windflower 


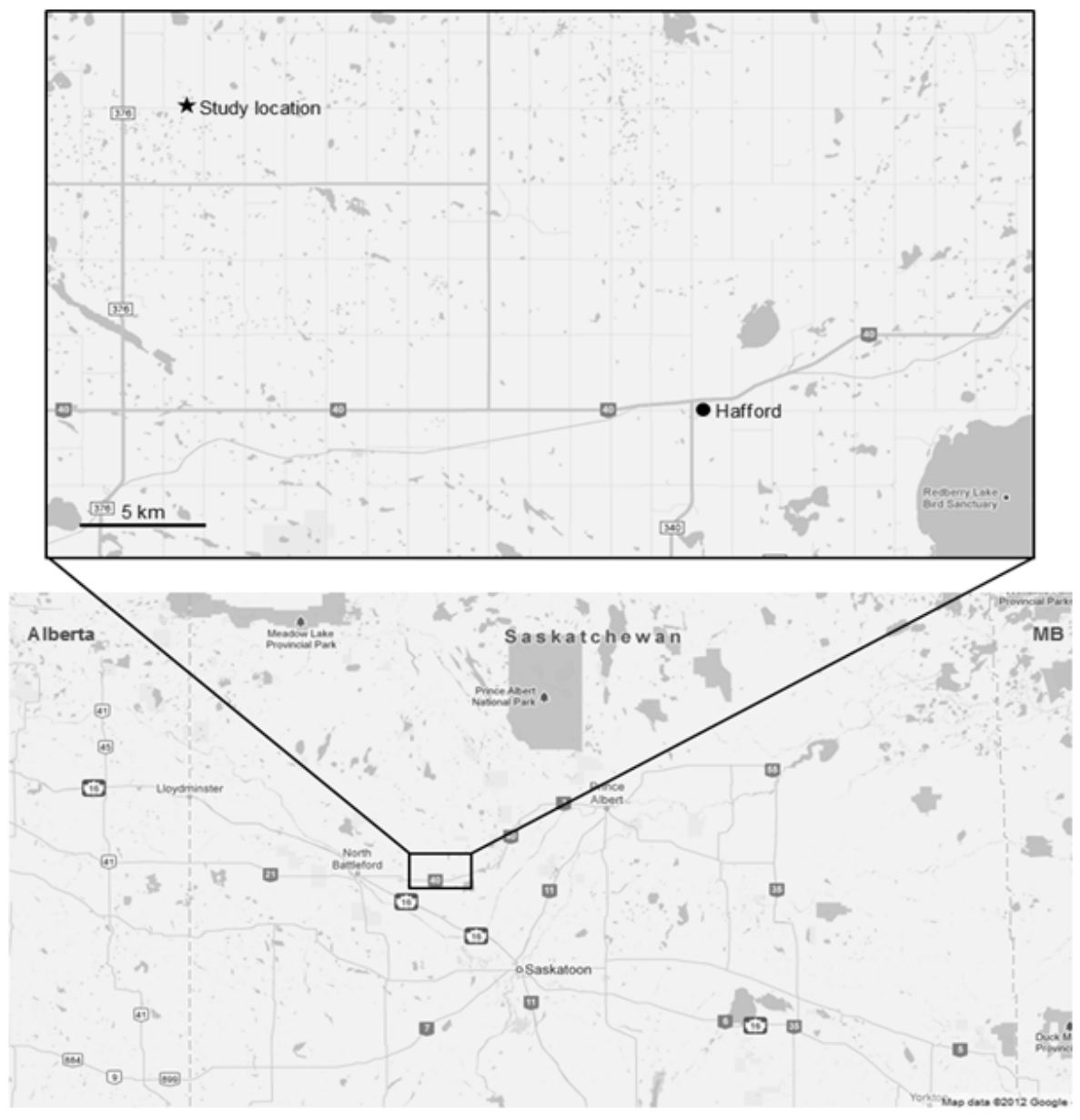

Figure 1. Location of the study population of Anemone patens near Hafford, Saskatchewan (N 52 $50^{\prime} 32^{\prime \prime}$ W 107³9'39").

and others. A. patens belongs to the buttercup or crowfoot family (Ranunculaceae). It is interesting that the major common name, prairie crocus, is incorrect and misleading from a scientific point of view. It was given to this plant by the European settlers that colonized the American prairies, as it reminded them of the true crocus of Europe, which in fact belongs to the genus Crocus in the iris family (Iridaceae).

While the vast majority of taxonomic treatments of the flora of Europe and Asia include this taxon under the genus Pulsatilla Miller, most American authors prefer to place it in the genus 
Anemone L. According to Dutton et al.. ${ }^{15} A$. patens is represented by the var. multifida in North America. However, there still remains some controversy over the taxonomic status of $A$. patens. Review of the major treatments and existing databases of the flora of Canada shows that the primary name for this taxon until the late-20 $0^{\text {th }}$ century was $A$. patens var. wolfgangiana, after which the majority of sources have used $A$. patens var. multifida. Although A. patens var. wolfgangiana is still being used by some authors (Table 1), A. patens var. multifida has priority and it should be applied as the legitimate name in modern floristic treatments.

There are two "atypical" colour forms of $A$. patens, with rose and white flowers respectively (Figure 2). A. patens var. rosea, characterized by pink flowers, has been described by Cockerell ${ }^{16}$ in North America. We found some plants belonging to the var. rosea during our field surveys in the city of Saskatoon (Crocus Prairie) in 2011. Albino individuals of $A$. patens have been described as var. albo-lutea in Europe ${ }^{17}$ and $\mathrm{f}$. stevensonis in North America. ${ }^{18}$ The holotype of the latter form is deposited in the AAFC National Collection of Vascular Plants and the specimen was collected in 1960 near Brandon, Manitoba by G.A. Stevenson, hence the name. Later, this form was found in two different locations near Carlyle, Saskatchewan by Silcox in 1995 (\#142755 SASK) $)^{19}$ and in 1998 (\#145264 SASK). ${ }^{19}$ We also observed a few plants identified as f. stevensonis during our field surveys in the city of Saskatoon (Northeast Swale) in 2012.

\section{Features of Life Cycle}

The mid-summer flowering individuals in the population of A. patens located northwest of Hafford (see Figure 1) were found to have abnormally light-coloured (almost white) tepals, in contrast to the normal pale lilac flowers. Although looking very similar to the plants with white flowers identified as $A$. patens $\mathrm{f}$. stevensonis, the individuals in the study population cannot be classified as belonging to this form. They are most likely individuals with bleached flowers. Because of the late flowering these plants were exposed to higher solar radiation and temperature regimes than in the spring which caused flower bleaching.

The mid-summer time of flowering (July) was also highly unusual, given that the normal flowering of $A$. patens in the region occurs from April to early May. ${ }^{7}$ To the best of our knowledge, no records exist of en masse flowering of $A$. patens in mid- 

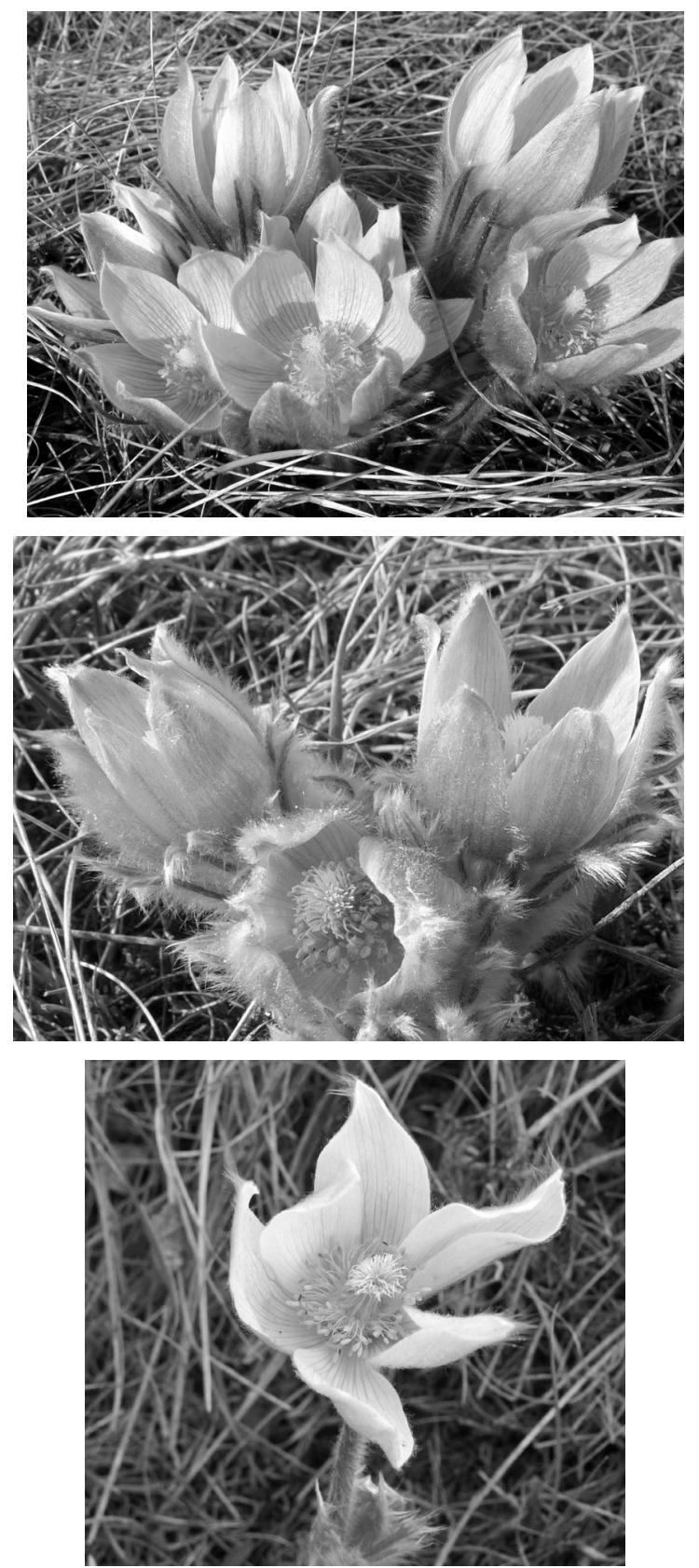

Figure 2. Prairie crocus (Anemone patens): top - typical flower form; mid - rose flower form; bottom - white flower form. (see inside front cover for colour images)

- Vladimir Kricsfalusy 
Table 1. Primary scientific names of Anemone patens in the Canadian floras and floristic databases

Taxon

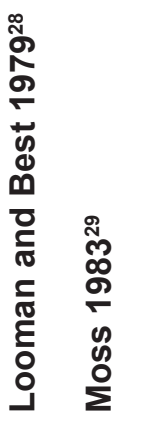

Anemone patens L.

A. patens L. var. multifida

Pritz.

A. patens L. var. + wolfgangiana (Besser) Koch

Pulsatilla patens (L.) Miller ssp. multifida (Pritz.) Zämelis
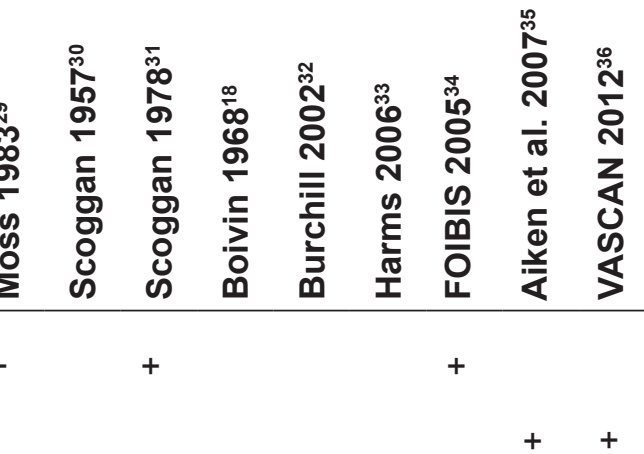

summer. There are only some indications that extent of the formation of leaf rosettes and of flowering and fruit-bearing shoots depends on weather conditions such as winter temperatures, snow cover, autumn precipitation, temperature, and sunshine duration in spring. ${ }^{20}$

According to Borisova, ${ }^{21}$ floral buds contain fully mature floral organs by June, allowing some individuals to flower for a second time in the early autumn (September) in Kazakhstan. In our opinion, this is the most likely explanation for the mid-summer repeated flowering we observed in the study population. Given that the population is located on intensive pasture, it is quite likely that the flowers produced in the spring failed to set seed due to grazing and trampling by cattle, which stimulated the development of the new fully formed flowering buds. This is supported by the fact that in 2011, new flowers significantly outnumbered old (dried) flower stalks from spring flowering, with most of the observed generative plants showing new flowers only. 
Secondly, the summer of 2011 was relatively wet for this climatic region, and the input of moisture may also have been a flowering stimulus. The consumption of the newly formed floral buds in the mid-summer repeated flowering would also explain the relative lack of flowering plants in the following season (2012).

\section{Community Ecology and Management}

The A. patens population near Hafford was situated on a pasture located on a gentle southfacing slope $\left(3^{\circ}\right)$. It was evidently strongly grazed and trampled by cattle, with a significant amount of bare soil $(30 \%)$, and showed no evidence of any recent burning. The vegetation community can be interpreted, according to the classification by Thorpe ${ }^{14}$, as Western Porcupine Grass Northern Wheat Grass - Sedge - Pasture Sage (Hesperostipa curtiseta - Elymus lanceolatus - Carex sp. - Artemisia frigida) type on the Loam Ecosite in the Aspen Parkland ecoregion. The vegetation cover was dominated by several graminoid species and a variety of forbs. In total, 33 vascular plant species were recorded within the $100 \mathrm{~m}^{2}$ plot (Table 2). Most species were native, but there was a significant presence of invasive plants such as Kentucky blue grass
(Poa pratensis), smooth brome (Bromus inermis), white sweet clover (Melilotus albus), yellow sweet clover ( $M$. officinalis), and dandelion (Taraxacum officinale). Overall, this grassland community experiences moderate to severe health alteration caused mainly by overgrazing and establishment of invasive plant species. Based on the vegetation structure and species composition this community is identified as only $52 \%$ similar to reference community Plain's Rough Fescue - Northern Wheat Grass - Western Porcupine Grass (Festuca hallii - Elymus lanceolatus - Hesperostipa curtiseta), which occurs in optimal growth conditions with reduced grazing impact.

In North America A. patens is strongly associated with native grasslands, ${ }^{3}$ particularly the endangered fescue prairie. ${ }^{22}$ Fescue prairie, which has declined to less than $1 \%$ of its original range in Saskatchewan, is an important grassland type for $A$. patens. In the study vegetation community, the cover of rough fescue (Festuca hallii) was estimated as being only $3 \%$, compared to $7 \%$ (of biomass) in the reference community. ${ }^{14}$ This indicates a decline of rough fescue and its potential loss in overgrazed grassland habitats.

A. patens has been reported to 
Table 2. List of vascular plant species recorded in the study population of Anemone patens near Hafford, Saskatchewan; vegetation community: Western Porcupine Grass - Northern Wheat Grass - Sedge - Pasture Sage (Hesperostipa curtiseta - Elymus lanceolatus - Carex sp. - Artemisia frigida); sampling plot: $10 \mathrm{~m}$ x $10 \mathrm{~m}$

\section{Plant Species}

Cover, $\%$

\section{Forbs}

Androsace septentrionalis L.

Anemone patens L.

Antennaria aprica Greene

Boechera grahamii (Lehmann) Windham \& Al-Shehbaz $\quad<1$

Artemisia campestris L.

Artemisia frigida Willd.

Astragalus agrestis Douglas ex G. Don

Erigeron caespitosus Nutt.

Geum triflorum Pursh

Heterotheca villosa (Pursh) Shinners

Melilotus albus Medik.*

Melilotus officinalis (L.) Lam.*

Oxytropis sericea Nutt.

Packera cana (Hook.) W.A. Weber \& Á. Löve

Potentilla concinna Richardson

Potentilla pensylvanica L.

Solidago missouriensis Nutt.

Solidago spathulata DC.

Symphyotrichum ericoides (L.) G.L. Nesom

Symphyotrichum laeve (L.) Á. Löve \& D. Löve

Taraxacum officinale F.H. Wigg. *

Thermopsis rhombifolia (Nutt. ex Pursh) Nutt. ex Richardson

Vicia americana Muhl. ex Willd.

Graminoids

Elymus lanceolatus (Scribner \& J.G. Smith) Gould ssp. lanceolatus $\quad 10$

Elymus trachycaulus ssp. subsecundus (Link) Á. Löve \& D. Löve <1

Bouteloa gracilis (Willd. ex Kunth) Lag. ex Griffiths 1

Bromus inermis Leyss. *

Carex duriuscula C.A. Meyer $\quad 20$

Festuca hallii (Vasey) Piper 3

Avenula hookeri (Scribner) Holub 1

Koeleria macrantha (Ledeb.) Schult.

Poa pratensis L. * 10

Hesperostipa curtiseta (Hitchcock) Barkworth 20

\section{Clubmosses}

Selaginella densa Rydb. 
flourish in the moderately grazed areas on prairies as it is not heavily relished by livestock. ${ }^{3,23}$ Our observations confirm these results and show that both an excess of disturbance and the absence of it are critical threats to the survival of A. patens. Adaptations for variable environmental conditions and management practices (different types of ontogenetic development, capacity for regeneration, etc.) provide this species with a series of mechanisms for coping with mild disturbances. ${ }^{7}$ On the other hand, the life history strategy of A. patens is based on individual survival rather than long range dispersion and colonization of new areas. ${ }^{7}$ This makes $A$. patens a weak competitor, unable to thrive in ungrazed, overgrown areas. A high density of tall grasses, forbs or shrubs and large amounts of litter will inhibit regeneration of $A$. patens due to heavy competition. Therefore, light to moderate grazing and management practices that reduce litter, control coarse grasses and open small patches of bare soil for seed germination favour populations of $A$. patens.

\section{Conservation Concerns}

The current status of $A$. patens in North America does not cause particular concern; however there has been reduction of the species range due to urbanization and agricultural development, ${ }^{6}$ as well as a decline in populations because of a lack of natural ecological processes or disturbances, such as grazing and fire, ${ }^{24}$ and impact of invasive plant species. ${ }^{25}$ Overall, $A$. patens is considered to be apparently secure (N4) at a national level for the whole United States. ${ }^{26}$ This species is not protected under the US Endangered Species Act, however its conservation status has been reviewed and ranked in six states: Wyoming (S4 apparently secure), Montana (S4), Utah (S1 - critically imperilled), Illinois (S1), lowa (S4), and Kansas ( $\mathrm{SH}$ - possibly extirpated).

In Canada $A$. patens is not protected under the Species at Risk Act. The species is classified as apparently secure (N4) at a national level by NatureServe. ${ }^{26}$ Nonetheless, the conservation status of $A$. patens varies between provinces. It is considered to be secure in Alberta, British Columbia, Manitoba and Saskatchewan, and as "may be at risk" in Nunavut and Ontario. Moreover, A. patens is included in a list of Rare Vascular Plants of Ontario. ${ }^{28}$

Ironically, in order to be protected, $A$. patens must be under some imminent (rather than longterm) threat of extinction. However, because habitat fragmentation is 
already threatening this species in Saskatchewan, studying its effects and long-term monitoring to get a better idea of how individuals and populations of $A$. patens cope with anthropogenic impact is of important scientific and conservation interest. Although species that are still relatively common, such as $A$. patens, can hardly be expected to be given legal protection, their association with threatened species may help them in many cases. At the same time, threatened plant species of native prairie may benefit from the results obtained during the study of $A$. patens, which can reveal useful information about vegetation community dynamics and trends.

\section{ACKNOWLEDGEMENTS}

We would like to thank John Kindrachuk for help with access to the study site in Hafford, SK (Redberry Lake Biosphere Reserve). We also thank V. Harms for reviewing the manuscript and his constructive and helpful comments. This research was partly supported by a President's NSERC grant from the University of Saskatchewan to the first author, and University of Saskatchewan Summer Student Employment Program (USTEP) funding to the second author.
1. Hultén E, Fries M (1986) Atlas of North European vascular plants north of the Tropic of Cancer, Vol. 1. Koeltz Scientific Books, Königstein.

2. Bilz M, Kell SP, Maxted N, Lansdown RV (2011) European Red List of vascular plants. Publications Office of the European Union, Luxembourg.

3. Wildeman AG, Steeves TA (1982) The morphology and growth cycle of Anemone patens. Canadian Journal of Botany 60:1126-1137.

4. Gauthier D, Wiken EB (2003) Monitoring the conservation of grassland habitats, Prairie ecozone, Canada. Environmental Monitoring and Assessment 88: 343-364.

5. Esparrago J, Kricsfalusy V (2014) Urban conservation and habitat preferences of Anemone patens L. in North America. Landscape and Urban Planning, (in press).

6. Kricsfalusy V, Gupta C, Li M (2014) Distribution and habitat affinities of Anemone patens L. (Ranunculaceae) in Saskatchewan, Canada. Canadian Field Naturalist (in press). 
7. Kricsfalusy V, Ponomarenko $Y(2014)$ Life cycle of the prairie crocus (Anemone patens L.) in natural populations of North America. Natural Areas Journal (in press).

8. Howarth D, Keane K (1995) Wild medicines of the prairies. Root Woman and Dave Publishers, Alvena, SK.

9. Moerman DE (2009) Native American medicinal plants: An ethnobotanical dictionary. Timber Press, Portland and London.

10. Brown A (1954) Old man's garden. Grey's Publishing, Sidney, BC.

11. Keane K, Howarth D, Courtney P (2009) The standing people: field guide of medicinal plants for the prairie provinces. $\left(2^{\text {nd }}\right.$ ed). Saskatoon, SK.

12. Small E, Catling PM, Brookes B (2012) A biodiversity treasure. Official plant emblems of Canada. Agriculture and Agri-Food Canada, Ottawa, ON.

13. Royal Canadian Mint (2010) Gold Coin - Prairie Crocus. Available: http://www.mint.ca/ store/coin/99999-gold-coinprairie-crocus-2010-prod820002 [Accessed April 8, 2012]
14. Thorpe J (2007) Saskatchewan Rangeland Ecosystems, Publication 4: Communities on the LoamEcosite. Saskatchewan Research Council, Regina, SK.

15. Dutton BE, Keener C, Ford B (1997) Anemone L. In: Editorial Committee of Flora of North America (ed) Flora of North America, Vol. 3. Oxford University Press, New York and Oxford, $p$ 139-158.

16. Cockerell TA (1888) West American Scientist (San Diego) 5: 5.

17. Zämelis A (1926) Beitragezur Kenntnis des Formenkreises Pulsatilla patens (L.) Mill. Acta Horticulturae Botanica, Universitatis Latvensis 1: 81-106.

18. Boivin B (1968) Flora of the Prairie Provinces, Vol. 16, No. 3. Université Laval, Québec City, QC.

19. SASK (2011) The W.P. Fraser Herbarium of the University of Saskatchewan (SASK). Saskatoon, Saskatchewan. Available from http://herbarium. usask.ca (accessed on 23 May 2011).

20. Wójtowicz W (2000) Biologia, wymagania siedliskowei 
możliwości uprawy zachowawczej Pulsatilla patens (L.) Mill. Biuletyn Ogrodów Botanicznych 9: 45-54.

21. Borisova IV (1961) Pulsatilla patens s.I. In: Lavrenko EM (ed) Steppe vegetation of Northern Kazakhstan. Academy of Sciences of the USSR Press, Moscow-Leningrad, p 84-87.

22. Vujnovic K, Wein RW and Dale MRT (2000). Factors determining the centrifugal organization of remnant Festuca grassland communities in Alberta. Journal of Vegetation Science, 11: 127-134.

23. Bruynooghe J, McDonald $R$ (eds) (2008) Managing Saskatchewan Rangeland. Available from http://www. saskforage.ca/publications/ ManagingRangeland.pdf (accessed on 30 June 2011).

24. Godwin B, Thorpe J (2004) Ten-year vegetation changes at Saskatoon Natural Grassland. Saskatchewan Research Council Publication 11658-1E04, Regina, SK.

25. Williams JL, Crone EE (2006) The impact of invasive grasses on the population growth of Anemone patens, a long-lived native forb. Ecology, 87/12: 3200-3208.

71 (3) September 2013
26. NatureServe (2012) NatureServe Explorer: An online encyclopedia of life. Version 7.0. Available from http:// www. natureserve.org/explorer (accessed 23 May 2012).

27. Oldham MJ, Brinker SR (2009) Rare Vascular Plants of Ontario. ( $4^{\text {th }}$ ed). Natural Heritage Information Centre, Ministry of Natural Resources of Ontario. Peterborough, ON.

28. Looman J, Best KF (1979) Budd's Flora of the Canadian Prairie Provinces. Research Branch, Agriculture Canada. Publication 1662. Canadian Government Publishing Centre, Hull, QC.

29. Moss EH (1983) Flora of Alberta. ( $2^{\text {nd }}$ ed). Revised by Packer JG. University of Toronto Press, Toronto, ON.

30. Scoggan HJ (1957) Flora of Manitoba. Available from http:// home.cc.umanitoba.ca/ burchil/ plants/ (accessed on 1 July 2011).

31. Scoggan HJ (1978) Flora of Canada, Vol. 3. National Museum of Canada, Ottawa, ON.

32. Burchill C (2002) List of plant families and genera in Manitoba. Available from http://home. cc.umanitoba.ca/ burchil/plants/ (accessed on 30 June 2011). 
33. Harms VL (2006) Annotated catalogue of Saskatchewan vascular plants. Available from http://www.parc.ca/saskflora/info (accessed on 30 June 2011).

34. FOIBIS (2005) Flora Ontario - Integrated Botanical Information System Phase I. Newmaster SG, Ragupathy S. University of Guelph, Guelph, ON. Available from http://www.uoguelph.ca/ foibis/ (accessed on 30 June 2011).
35. Aiken SG, Dallwitz MJ, Consaul LL et al. (eds) (2007) Flora of the Canadian Arctic Archipelago: descriptions, illustrations, identification, and information retrieval. [CD-ROM]. National Research Council of Canada, Ottawa, ON.

36. VASCAN (2012) Database of vascular plants of Canada. Available from http://www. canadensys.net/activities/ development/vascan (accessed on 21 April 2012).

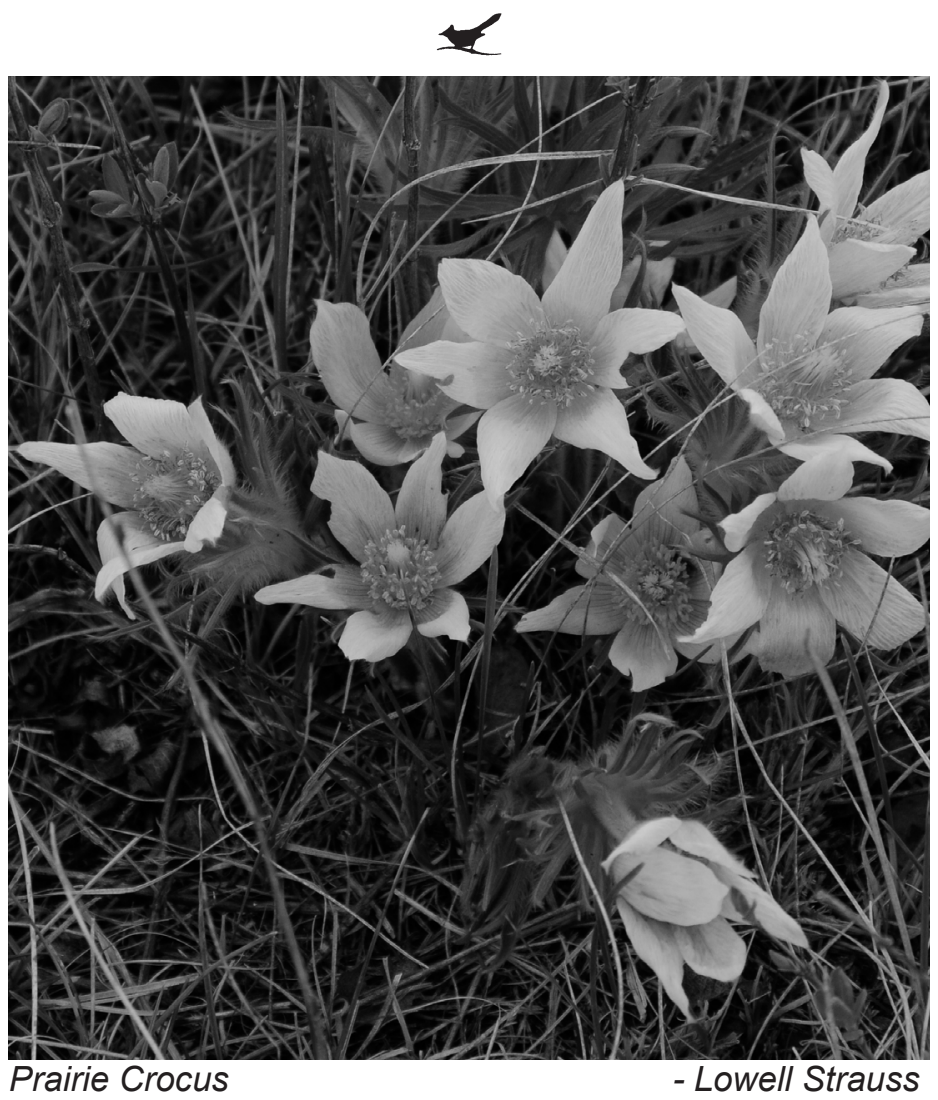

